\title{
專門委員会・分科会研究レビュー
}

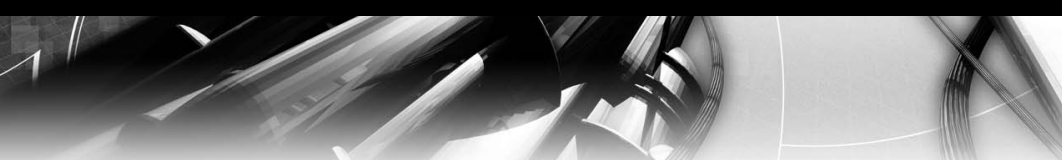

成形プラスチック歯車研究専門委員会

\section{高強度化・高精度化するプラスチック歯車, その適用範囲のさらなる搪大を目指しで \\ Plastic Gears with More Load Capacity and Accuracy, Approach to Their Wider Application}

\section{森脇一郎** 上田昭夫*** \\ Ichiro MORIWAKI and Akio UEDA}

\section{1. は じめに}

専門委員会・分科会研究レビューは, 数ある専門委員 会・分科会からいくつかの会が選ばれ，執筆を依頼される もので, 当委員会は, 2002 年に, 初代委員長である青山 学院大学名誉教授岩井實先生が執筆されて以来, 6 年ぶり の報告となる．

成形プラスチック歯車研究専門委員会は, 上述のよう に, 青山学院大学教授 (当時) 岩井實先生が 1992 年に, 企業会員 25 社, 専門委員 21 名で立ち上げられた。その前 身は, 1986 年から 2 期 6 年続いた日本機械学会の調査研 究分科会であったが，もっと自由に研究を行いたいという ことで精密工学会の専門委員会に活動の場を変えられたの が始まりとなる.したがって, 前回の岩井先生による報告 は, ちょうど 10 年の節目を越えた時期のものであった。

そして，2003 年より，宮城工業高等専門学校教授（当 時）庄司彰先生が 2 代目委員長に就任され, 事務局も東京 から大阪に移転し，さらなる発展を迎えることになる。15 周年記念誌「成形プラスチック歯車研究専門委員会の足跡 一最近 5 年間の歩み一」によると, 10 周年を過ぎて以降, 企業会員が 13 社増えたという。プラスチック歯車が用い られる理由は, 低騒音, 軽量, 無潤滑, 低コストが主なも のであり, それは今もかわらない. しかし, 岩井先生を委

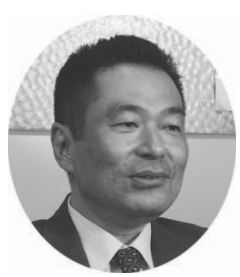

003 年 1 月より 院工芸科学研究科機械システム工学部門教授.工 学博士. 研究領域は, 歯車を対象とした加工シミュレーション, 設計シス テム等の開発。

上田昭夫

1983 年アムテック(有)を設立. 代表取締役. 歯車技術に関するソフトウェ アの開発と経営に従事. 現在, 京都工芸纎維大学大学院工芸科学研究科博 士後期課程に在学中. 成形プラスチック歯車研究専門委員会幹事.
員長として活動された 10 年の間に, 材料開発, 金型加 工・成形加工技術の進歩, CAE 技術の革新に伴う設計技 術の進化などが大きく進み, 高強度化・高精度化が実現 し，この 5 年間で，プラスチック歯車の適用範囲が大きく 広がったことに起因するものと思う.

本稿では, 筆者が, 庄司先生の後を引き継ぎ, 2007 年より 3 代目の委員長を拝命して以後の, さらなる適用範囲拡大 を目指す当委員会の活動を報告するとともに, 当委員会の 研究会で取り上げたホットな話題をいくつか紹介する.

\section{2. 最 近の 活 動}

成形プラスチック歯車研究専門委員会の 2008 年 6 月 13 日現在での会員数は, 正会員 (企業会員) 42 社, 個人会 員 (専門委員) 19 名である. 年間行事は, 2 月の総会, 研 究会 5 回, 見学会 1 回, 講習会 1 回, およびこれらの運営 を議論する運営委員会を 6 回行っている. 研究会では材料 技術，金型加工技術，成形技術，歯車設計技術などに関す る最新情報を, それらの技術に直接携わっておられる技術 者を講師に迎え, 講演会形式でお届けしている。講習会で は, これらの技術に関する基礎事項を, 専門の研究者, 技 術者を講師に迎え, 講義形式で懇切丁寧に解説している. 見学会では，成形プラスチック歯車に係わる業界で注目さ れている企業や研究機関を訪問し, その生産設備や研究設 備を見学させていただいている。ただ最近, 競争が激化し ているためか, 技術の公開に躊躇する企業が増え, 見学先 を選ぶことに苦労させられている．多くの技術者がよく似 た問題で同じように悩んでいる。 それらの技術者が, 当専 門委員会のような学会活動を通して, 協力し合うことがで きれば，日本企業のさらなる競争力増強につながるものと 期待できる. Global な世界で生きていくことは“日本” という概念を取り払うことと考えている方も少なくないよ うであるが全く逆である，Global な世界で生き残るため には強く“日本”を意識しなければならない. 日本企業で はなく，企業を優先せざるを得ない現状は残念なことであ る.

また, 委員会下に, 強度, 騒音, 強度規格の 3 つの小委 
員会を作り，個別のテーマについて調査・研究活動を行っ ている.

強度小委員会では，鋼ウォームとプラスチックヘリカル ホイール（ポリアセタール）の組み合わせによる運転試験 を行い, 破壊形態, 歯面温度, 伝達効率, 摩擦係数につい て検討し，強度設計に資する情報の提供を目指している。

騒音小委員会では, 当分野では “永遠の課題”であるギ ヤノイズ低減を目的に設置されたもので，文献調査や発生 要因の追求に関する経験を議論する後援会活動を中心に活 動を行っている. 現在, これまでに得られた知見を小冊子 にまとめる作業が続いている.

強度規格小委員会では，十分な知識をもたずにプラスチ ック歯車を採用して事故を起こしたり，うまく設計すれば プラスチック歯車の採用が可能でコスト削減や軽量化がで きるのにその検討すらしていない事例が多いという認識の 下に，誰もが簡単に“使える”設計式を作ることを目的に 設置された。将来的にはJISやISOに提案し，規格化す ることも念頭に置き, 日本歯車工業会の成形プラスチック 歯車部会とも連携して活動を行っている。

\section{3. 研究助成活動}

成形プラスチック歯車研究専門委員会では，個人会員の 中から，この分野の技術の発展に寄与が期待できる研究に 研究助成も行っている. 2007 年度は, 表 1 の 4 件に対し 助成を行った。

\section{4. 最近のトピックス}

\section{1 照射架橋樹脂テラリンク}

“テラリンク『は, 住友電工ファインポリマー(株)が 出している電子線を照射することにより架橋するエンジニ アリングプラスチックである．摺動グレードの一つである ナイロンをベース樹脂としたテラリンク N66N02A は歯車 材料として, 今, 注目されている. 同社によると, 耐摩耗 性, 耐熱性, 鞎性に優れ, またクリープが少なく, かつ疲 労強度にも優れているとのことである.

テラリンクの製造工程は, ベース樹脂に特殊なコンパウ ンドを混ぜ，それを射出成形し，その後，電子線を照射す るというものである。ナイロンはそのままでは電子線照射 による架橋が進みにくい材料のようで，特殊な架橋剤が必 要とのことである。また，電子線は大気中で照射できるこ

表 12007 年度研究助成

\begin{tabular}{|c|c|c|}
\hline 研究者名 & 所属 & 研究テーマ \\
\hline 扇谷保彦 & 長崎大学 & $\begin{array}{l}\text { 動力伝達用ナイロン歯車の低騒音化に } \\
\text { 関する研究 }\end{array}$ \\
\hline 黒河周平 & 九州大学 & 微小モジュール歯車の歯面精度計測 \\
\hline 滝 晨彦 & 岡山理科大学 & $\begin{array}{l}\text { 成形プラスチック歯車の強度に与える } \\
\text { 污肌膜の影響 }\end{array}$ \\
\hline 森川浩次 & 佐世保高専 & $\begin{array}{l}\text { 伝動パワーステアリング用ナイロンウ } \\
\text { オームホイールの負荷能力に関する研 } \\
\text { 究 }\end{array}$ \\
\hline
\end{tabular}

とから装置が簡単になるようであるが，実際には照射する 電子線が, 電圧が $0.1 〜 10 \mathrm{MV}$ ，電流が数 $10 \mathrm{~mA}$ と非常に 高いエネルギーのもののようで，また放射線に対する厳し い規制もあり，たいそう大がかりな（3 階建てのビル相 当）装置になり，成形メーカなどが容易に導入できる規模 ではないようである。

非架橋のナイロンとは比べものにならないほど, 高い耐 摩耗性, 耐熱性を示したという話も聞いているが.一方 で，それほどの効果は認められなかったという情報も耳に しており，今後の歯車を用いた詳細なテストが待たれると ころである。

\section{2 プラスチック歯車の X 線測定}

医療用の X 線 CT 検査装置の産業用版とでもいうもの で，(株)島津製作所やカールツァイス $\operatorname{IMT}($ 株)等が，マ イクロフォーカス X 線 CT 装置や産業用 X 線 CT スキャ ナ等の名称で出している非破壊検査装置が, 今, 注目され ている，成形品はどうしても内部欠陥が問題となるが，こ れを非破壊で定量的に検査ができる可能性が出てきたこと は喜ばしいことと思う。まだまだ測定時間やデー夕処理ソ フトに多くの改善の余地がありそうに思えるが，今後に期 待できる技術である.

\section{3 樹脂流動解析ソフトの最新動向}

CAE ツールとして最も進んでいるものの一つである樹 脂流動解析ソフトは, ハードウェアの高速化に伴って, 大 規模化の方向に向かっている。 また, 繰り返し計算を行っ てゲート位置などの最適化まで行われるようになってき た。最適化条件は設計者の考え方に依存するため，ソフト のカスタマイズが進んできている. カスタマイズの進展 は, 解析精度向上という, 昔からの流れとも相まって, 益々進んでいくのではないだろうか.

また, 精密成形加工に対応するため, 金型の温度分布の 解析にとどまらず，近年は金型の変形をも解析するシステ ムが現れている。 ウエルドの位置や強化繊維の配向, さら にそりや変形の状態を解析するとともにこれらを考慮した 強度解析をしたいという要求が強く出てきており，これら への対応が可能となる日も近いのではないだろうか.

\section{4 プラスチック歯車の精度}

プラスチック歯車も金属歯車同様に高精度が要求されて いるが，プラスチック歯車の精度規格は, JIS B 1702-1, -2 やJGMA 116-02 を使用しているのが現状である。しか し, JIS B 1702-1 の最小モジュールは 0.5 であるため小モ ジュールが多いプラスチック歯車では適用することができ なかった，そこで 2003 年に当委員会のメンバーが中心に なって作成したプラスチック歯車の特性を考慮した精度規 格 JIS B 1702-3 が 2008 年 4 月に公表された。今後，プラ スチック歯車の精度規格の活用が期待される。

\section{5 プラスチック歯車の用途拡大}

プラスチック歯車の用途は拡大している。1998 年の当 委員会の調査では国内における 1 力月の使用数は 5 億 6 千 万個であったが, 現在はさらに増加していると予想する. 
例えば，現在，自動車に使用される小型モー夕は大衆車で は 70〜80 個, 高級車では 100 個程度使用され, それには 必ず減速機構としてプラスチック歯車が多数使用されてい る。これらの歯車は高精度, 高強度, 高耐久性が要求され るものであり, 今後, 従来の金属歯車からプラスチック歯 車に，また，切削品から成形品に変更される歯車がますま す増加するものと思われる。

\section{5. お りに}

歯車という非常に古典的な機械要素を対象として調査・ 研究活動を進めているが，これはいわゆるローテクであ る。その語の印象から，八イテクとは高いレベルの技術 で，ローテクとはレベルの低い技術と誤解している人が少
なからずいるようである。筆者の友人が力説しているのだ が，ハイテクとは“ハイリスクハイリターンの技術”で, ローテクとは“ローリスクローリターンの技術”である. つまりこれまで先人たちによってコッコツと積み上げられ てきた技術に支えられているため，リスクはさほど大きく ないが, 社会の劇的な変化をもたらし大きなリターンが得 られるというものでもない. しかしそこで行われている研 究は，地道なものであるが，最先端であることには変わり がない，ものづくりを支えているのは，ここでいう“ロー テク”である。ドイツがものづくりで他の国とひと味違う のは, この“ローテク”を重視し, 頑固にコッコッ積み重 ねているからに他ならない. 当専門委員会もコッコッと今 後も地道に頑固にこの道を進んでいきたいと思う. 